\title{
Autism and vaccinations: Does google side with science?
}

\section{Otizm ve aşılar: Google bilimin yanında mı?}

\author{
(1) Semih Erden, ${ }^{10}$ Kevser Nalbant, ${ }^{2}$ (1) Hurşit Ferahkaya ${ }^{1}$ \\ 'Department of Child and Adolescent Psychiatry, Necmettin Erbakan University Faculty of Medicine, Konya, Turkey \\ ${ }^{2}$ Department of Child and Adolescent Psychiatry, Hacettepe University Faculty of Medicine, Ankara, Turkey
}

\begin{abstract}
Introduction: Genetic and environmental factors are thought to play a role in the etiology of autism spectrum disorder. Studies on vaccination, which is one of the environmental factors, suggest that there is no relationship between vaccines and autism development. However, a part of society still believes that vaccines lead to autism. Therefore, we aimed to investigate the distribution and reliability of the articles on the internet, which is the first place to which families refer for information about this subject.

Methods: In this study, we searched the term autism vaccine in Google's version for Turkey. The information on each website was grouped as accurate, incorrect, and contradictory. We used the JAMA score, a standard indicator of health information quality, to assess the basic reliability index of the article. The JAMA score takes into account whether a website declares an author, the date of writing, financial ownership, and whether the information is supported by references.

Results: A total of 124 websites were listed as a result of this search. When irrelevant and inaccessible sites were removed, 102 web pages were evaluated. The information obtained from 76 (74.5\%) websites was accurate, 20 (19.6\%) websites contained incorrect information, and $6(5.9 \%)$ presented contradictory information. Although the JAMA score of the sites containing the accurate information was higher than the sites with incorrect information, the difference between them was not statistically significant. In terms of the information given in the content of the internet sites, it was found that six of the top ten sites were accurate, three were incorrect, and one was contradictory. No statistically significant relationship was found between the accuracy of the information and the ranking of the sites.

Discussion and Conclusion: These results show that accurate information is not listed primarily in the top positions, and that information about autism and vaccination has similar distribution. It is important to increase the number of articles and projects aimed at informing society about autism and vaccination through the internet by scientists and government officials and to ensure that families have access to accurate information
\end{abstract}

Keywords: Autism; google; internet; public health; vaccine.
Özet

Amaç: Otizm spektrum bozukluğunun etyolojisinde genetik ve çevresel faktörlerin rol oynadığı düşünülmektedir. Çevresel faktörlerden aşı ile ilgili yapılan çalışmalar, aşı ile otizm gelişimi arasında ilişki olmadığını göstermiş olmasına karşın toplumun bir kesimi hala aşıların otizme yol açtığına inanmaktadır. Bu çalışmada, bu konu ile ilgili ailelerin bilgi sahibi olmak için başvurdukları ilk yer olan internetteki aşı ve otizm ile ilgili yazıların dağılımı ve güvenilirliği araştırılmıştır.

Gereç ve Yöntem: Bu çalışmada, Google'un Türkiye sürümünde "otizm aşı" ifadesi aranmış, her sitedeki bilgiler doğru, yanlış ve çelişkili olarak gruplandırılmıştır. Yazıların temel güvenilirlik endeksini değerlendirmek için sağlık bilgi kalitesinin standart bir göstergesi olan JAMA puanını kullanılmıştır. JAMA puanı, bir web sitesinin yazar ilan edip etmediğini, yazılma tarihini, finansal sahipliğini ve bilgilerin referanslarla desteklenip desteklenmediğini dikkate almaktadır.

Bulgular: Yapılan arama sonucunda toplam 124 internet sitesi listelenmiş, alakasız ve ulaşılamayan siteler çıkarıldığında 102 site değerlendirmeye alınmıştır. Bu internet sitelerinin76'sının (\%74.5) doğru, 20'sinin (\%19.6) yanlış, 6'sının (\%5.9) ise çelişkili bilgiler içerdiği saptanmıştır. Doğru bilgi içeren sitelerin JAMA puanının yanlış bilgi içeren sitelere göre daha yüksek olmasına rağmen aralarındaki fark istatistiksel olarak anlamlı bulunmamıştır.Internet sitelerilerinin içeriğindeki bilgiler açısından ilk on sitenin altısının doğru, üçünün yanlış ve birinin çelişkili olduğu tespit edilmiştir. Bilgilerin doğruluğu ile sitelerin sıralaması arasında istatistiksel olarak anlamlı bir ilişki bulunmamıştır.

Sonuç: Bu sonuçlar, doğru bilgilerin öncelikle üst sıralarda listelenmediğini, otizm ve aşı konusunda bilgilerin benzer dağıldığını göstermektedir. Bilim insanları ve devlet yetkilileri tarafından internet ortamı aracılığıyla otizm ve aşı ile ilgili toplumu bilgilendirme amaçlı yazıların ve projelerin arttırılarak ailelerin doğru bilgilere ulaşmalarının sağlanması önemlidir.

Anahtar Sözcükler: Otizm; google; internet; halk sağlığl; aşı. 
A utism spectrum disorder (ASD) is a neurodevelopmental disorder with symptoms beginning in the early childhood period characterized by limited social interaction, areas of interest, and communication. The increasing prevalence of ASD has been reported to be 1/68-1/59 in recent studies. ${ }^{[1,2]}$ Many genetic and environmental factors have been studied in research exploring the etiopathogenesis of ASD. Studies have led to the consideration that reciprocal interactions of many factors play a role in the etiology of ASD, rather than a single factor.

Childhood vaccinations are the most cost-effective method to provide protection against infectious diseases, which reduces death and disability worldwide. ${ }^{[3]}$ Vaccinations ensure protection against disease through individual immunity, but also ensure communal immunity by reducing contact between unvaccinated individuals and disease vectors due to the presence of vaccinated individuals. Thus, the incidence rate of disease is reduced through herd immunity. However, childhood vaccination is one of the environmental factors blamed for the etiology of ASD. As the prevalence of ASD and the increase in communal vaccination coincided with approximately the same period, vaccines were accused of causing ASD. This issue has lately become an essential general health issue with vaccine-preventable diseases increasing in the community due to the fear of a claimed link between vaccinations and ASD. ${ }^{[4]}$ In this context, an article supporting the link between measles, mumps, and rubella (MMR) vaccinations and autism was published by Andrew Wakefield in the Lancet in 1998. ${ }^{[5]}$ When it was understood that the results were incorrect, the Lancet retracted the article in 2010. ${ }^{[6]}$ Subsequently, other studies suggested a link between the MMR vaccine and $\mathrm{ASD}_{1}{ }^{[7]}$ and concerns were raised that the ethyl mercury included in other vaccines as a preservative might increase the risk of ASD. ${ }^{[8,9]}$ Conversely, well-designed studies in various countries have shown that there is no connection between vaccination and ASD. ${ }^{[10-13]}$ One case-control study showed that there was no connection between ethyl mercury and ASD $^{[14]}$ Furthermore, according to two meta-analytic articles, there were no correlations between exposure to vaccine/ethyl mercury and $\mathrm{ASD}^{[4,15]}$ Finally, a recent review reported strong evidence refuting the hypothetical role of vaccination in the etiology of $\mathrm{ASD}^{[16]}$ In spite of these research results, there are still fears in the community that childhood vaccines or vaccine compounds are risk factors for the development of ASD, and vaccinations have continued to be a source of concern for parents and increasing numbers of anti-vaccination groups have been observed in recent years.

The internet is an important mass communication tool, which makes it easy to access information. Internet technologies have brought innovation to many areas of our lives involving information sharing from public services to trade, from social relationships and entertainment to intercultural interaction, and in providing news. A study stated that one of the most important reasons for people using the internet was to search for information related to health. ${ }^{[17]}$ Addition- ally, some studies reported that information on vaccines on the internet adversely affected parents and caused vaccine rejection. ${ }^{[18,19]}$ As a result, the importance of researching the accuracy of the information in the online network gains importance each day due to its effect on parental decisions regarding childhood vaccinations. There are still very few studies evaluating the accuracy of information about vaccination in online networks. To the best of our knowledge, no studies have evaluated online data about vaccination and ASD etiology in our country, Turkey. This study aimed to research the distribution and reliability of articles about "autism and vaccinations" on internet websites, which families visit daily to obtain information.

\section{Materials and Method}

The study was performed using the Turkish Google interface for the key terms otizm aşı (Turkish words for autism and vaccination) in May of 2019. No other word was added to prevent the search engine from being affected by other words. Before completing the research, cookies and the search history were deleted from the computer to prevent the effect of previous search results. The search was completed after logging out of the Google account. The internet address typed for the search was www.google.com.tr.

The search results accessed 124 websites. These websites were transferred to a table and visited separately according to the list in the table. Twenty-two websites unrelated to the search terms or which could not be accessed were excluded from the analysis. The typology of each website was recorded. The typologies were grouped as commercial, government, health portal, news, non-profit, professional, and scientific journals. Websites that did not comply with any category or which were difficult to classify were listed as "other."

If the information on the website clearly stated that vaccinations did not cause autism it was grouped as 'accurate'; if the inverse was stated it was grouped as 'incorrect,' and if the website contained both accurate and incorrect information or did not give a clear message, it was grouped as 'contradictory. 'To evaluate the basic reliability index for the articles, JAMA points (the standard marker for health information quality) were used. JAMA points note whether the author is credited on the website, the date of publishing, financial ownership, and whether the information is supported by references.

\section{Statistical analysis}

The Statistical Package for the Social Sciences (SPSS) version 15.0 was used for statistical analysis. For the assessment of data, the Pearson correlation test was used for correlations between data, the Mann-Whitney $\mathrm{U}$ test and Spearman correlation test were used for non-parametric data. For the evaluation of categoric data, the Chi-square test was used. For all statistical procedures, the significance level was accepted as $p<0.05$, and all tests were two-tailed. 


\section{Results}

\section{Website typology and content}

According to the search results, a total of 102 websites were taken into analysis. When the type of website was investigated, most (31.4\%) were observed to be news sites (Table 1 ). The distribution of the information on the websites according to the search results was given in Table 2 . We grouped websites as government and professional sites and others that took scientific resources into account (Table 3). As seen in Table 3, there were no significant differences in terms of the distribution of accurate and incorrect information according to website groups. Additionally, it was found that most of the websites (74.5\%) contained accurate information (Table 2). When the correlation between the accuracy of the information on the websites and their listing on Google was analyzed, no statistically significant difference was found (Table 4). However, when the distribution of the authors and page listings were analyzed, articles with unnamed authors were found on the first two pages in a statistically significant manner $(p<0.05)$. The distribution of the information on the websites according to the authors was given in Table 5. Authors in our study, divided into two groups as medical doctor and others. There was no statistically significant difference was found between

\section{Table 1. Search results according to website typology}

\begin{tabular}{lcc} 
Typology & \multicolumn{2}{c}{ Website } \\
\cline { 2 - 3 } & $\mathbf{n}$ & $\%$ \\
\hline Commercial & 11 & 10.5 \\
Government & 1 & 1 \\
Health portal & 13 & 12.4 \\
News & 33 & 31.4 \\
Non-profit & 28 & 26.7 \\
Professional & 11 & 10.5 \\
Scientific journals & 5 & 4.8 \\
Other & 3 & 2.9
\end{tabular}

Table 2. Search results according to the distribution of website contents

\begin{tabular}{|c|c|c|c|c|c|c|}
\hline \multirow[t]{3}{*}{ Typology } & \multicolumn{6}{|c|}{ Content } \\
\hline & \multicolumn{2}{|c|}{ Accurate } & \multicolumn{2}{|c|}{ Incorrect } & \multicolumn{2}{|c|}{ Contradictory } \\
\hline & $\mathbf{n}$ & $\%$ & $\mathbf{n}$ & $\%$ & $\mathbf{n}$ & $\%$ \\
\hline Commercial & 8 & 72.7 & 1 & 9.1 & 2 & 18.2 \\
\hline News & 21 & 63.6 & 9 & 27.3 & 3 & 9.1 \\
\hline Health portal & 10 & 76.9 & 3 & 23.1 & - & - \\
\hline Non-profit & 22 & 78.6 & 6 & 21.4 & - & - \\
\hline Government & 1 & 100 & - & - & - & - \\
\hline Professional & 10 & 90.9 & 1 & 9.1 & - & - \\
\hline Scientific journals & 4 & 80 & - & - & 1 & 20 \\
\hline Total & 76 & 74.5 & 20 & 19.6 & 6 & 5.9 \\
\hline
\end{tabular}

the groups of authors in terms of correct and incorrect information (Tablo 6).

\section{JAMA points}

There was no statistically significant difference found for JAMA points of websites containing accurate, incorrect/contradictory information (Table 7). However, JAMA points were higher for accurate information. The JAMA scores of scientific journals, professional, and government website groups were significantly higher than other sources (Table 8).

There was no statistically significant correlation between JAMA points and website listings. Additionally, of the 10 results on the first page of the search, six contained accurate information, three contained incorrect information, and one was contradictory. Thirty-nine percent of the websites had references; $43.4 \%$ of those with accurate information had references, and $34.8 \%$ of the websites with incorrect information had references. None of the pages with contradictory information contained references.

Table 3. Search results according to the groups of website

\begin{tabular}{|c|c|c|c|c|c|}
\hline \multirow[t]{3}{*}{ Typology } & \multicolumn{4}{|c|}{ Content } & \multirow{3}{*}{ Statistic } \\
\hline & \multicolumn{2}{|c|}{ Accurate } & \multicolumn{2}{|c|}{$\begin{array}{c}\text { Incorrect/ } \\
\text { Contradictory }\end{array}$} & \\
\hline & $\mathbf{n}$ & $\%$ & $\mathbf{n}$ & $\%$ & \\
\hline $\begin{array}{l}\text { Scientific journals, } \\
\text { professional and } \\
\text { government }\end{array}$ & 15 & 88.2 & 2 & 11.8 & $X^{2}: 2,023^{\text {NS }}$ \\
\hline Others & 61 & 71.8 & 24 & 28.2 & \\
\hline
\end{tabular}

NS: Not significant.

Table 4. Google listing of websites according to content

\begin{tabular}{lcc} 
Content & $\begin{array}{c}\text { Website listing } \\
\text { Mean } \pm \text { SD }\end{array}$ & t-test \\
\hline Accurate & $54.11 \pm 31.62$ & $\mathrm{~F}=2,784^{\mathrm{NS}}$ \\
Incorrect/Contradictory & $60.04 \pm 38.60$ & \\
\hline
\end{tabular}

SD: Standard deviation; NS: Not significant.

Table 5. Distribution of content according to the author

\begin{tabular}{|c|c|c|c|c|c|c|}
\hline \multirow[t]{3}{*}{ Author } & \multicolumn{6}{|c|}{ Content } \\
\hline & \multicolumn{2}{|c|}{ Accurate } & \multicolumn{2}{|c|}{ Incorrect } & \multicolumn{2}{|c|}{ Contradictory } \\
\hline & $\mathbf{n}$ & $\%$ & $\mathbf{n}$ & $\%$ & $\mathbf{n}$ & $\%$ \\
\hline Medical doctor & 25 & 83.3 & 5 & 16.7 & - & \\
\hline Expert in variety of areas & 3 & 75 & 1 & 25 & - & \\
\hline Journalist & 8 & 66.7 & 4 & 33.3 & - & \\
\hline Unknown & 40 & 70.2 & 12 & 21.1 & 5 & 8.8 \\
\hline No expertise & - & - & 1 & 50 & 1 & 50 \\
\hline
\end{tabular}


Table 6. Distribution of content according to author type

\begin{tabular}{|c|c|c|c|c|c|}
\hline \multirow[t]{3}{*}{ Author } & \multicolumn{4}{|c|}{ Content } & \multirow{3}{*}{ Statistic } \\
\hline & \multicolumn{2}{|c|}{ Accurate } & \multicolumn{2}{|c|}{$\begin{array}{c}\text { Incorrect/ } \\
\text { Contradictory }\end{array}$} & \\
\hline & $\mathbf{n}$ & $\%$ & $\mathbf{n}$ & $\%$ & \\
\hline Medical doctor & 25 & 83.3 & 5 & 16.7 & $X^{2}: 1,742^{\text {NS }}$ \\
\hline Others & 51 & 70.8 & 21 & 29.2 & \\
\hline
\end{tabular}

NS: Not significant.

Table 7. JAMA points according to content

\begin{tabular}{lccc}
\hline \multirow{2}{*}{ Content } & \multicolumn{2}{c}{ JAMA points } & Statistic \\
\cline { 2 - 3 } & Median & Min.-Max. & \\
\hline Accurate & 2 & $0-4$ & $\mathrm{X}^{2}=781,000^{\mathrm{NS}}$ \\
Incorrect/Contradictory & 2 & $0-4$ & \\
\hline
\end{tabular}

Min.: Minimum; Max.: Maximum; NS: Not significant.

Table 8. JAMA points of websites

\begin{tabular}{lccc} 
Typology & \multicolumn{2}{c}{ JAMA points } & Statistic \\
\cline { 2 - 3 } & Median & Min.-Max. & \\
\hline $\begin{array}{l}\text { Scientific journals, } \\
\text { professional and, }\end{array}$ & 3 & $0-4$ & U: $382,000^{* *}$ \\
government & 2 & $0-4$ & \\
Others & 2 & & \\
\hline
\end{tabular}

Min.: Minimum; Max.: Maximum; ${ }^{* *} \mathrm{p}<0.001$

\section{Discussion}

The aim of the study was to analyze the content and reliability of websites related to "autism and vaccination." To date, studies researching the information content on Google related to surgical and psychiatric diseases have been performed in different countries. However, to the best of our knowledge, no studies have researched the content and reliability of websites related with autism and vaccinations in Turkey. In this study, according to the search results from Google's Turkish interface, though there was no statistically significant difference in terms of the distribution of information related to autism and vaccinations on the websites, it appeared that there was more accurate information listed.

When the distribution of websites was examined in our study, news sites and non-profit sites about autism and vaccinations were found to be more common, with relatively fewer articles from government sources and scientific journals. This finding shows that the topic of autism and vaccination is a popular topic. A study reported that in the context of vaccination and autism, Twitter directed the news agenda, and the social information and discussion platform 'Reddit' monitored this agenda. ${ }^{[20]}$ A study that researched website content related to autism and vaccination in many languages reported fewer articles from government sources. ${ }^{[21]}$ However, there is also study reporting more government-supported website related to flu vaccination..$^{[22]}$ This may be explained by governments becoming more involved in strong vaccination campaigns considering the effect of the flu virus in terms of morbidity and mortality. Finally, according to our data, it is our belief that the authorities organizing the state's health care policy in Turkey need to be more involved in this process.

When the information related to vaccinations was examined on the websites, it appeared that there were three times more websites containing accurate information than those containing incorrect information in our study. Similar studies of Google interfaces from different countries reported that accurate information was found at least two or three times more frequently compared with incorrect information. ${ }^{[21]}$ A study comparing the information in 84 websites stated that $16.7 \%$ of websites contained at least one myth in information in the context of autism-vaccination. ${ }^{[23]}$ Another study analyzing YouTube videos reported that information supporting antivaccination was found three times more frequently than those with accurate information. Venkatraman et al. compared information found on YouTube with information obtained from Google, Wikipedia, and PubMed, and observed that information on YouTube clearly supported the presence of a connection between vaccination and autism. ${ }^{[15]} \mathrm{A}$ study in America investigated 100 popular videos about autism on YouTube and reported that $16 \%$ of videos contained incorrect information related to vaccinations. ${ }^{[16]}$ In our study, search results from the Google search engine found that the first website with incorrect information about autism and vaccinations was second in the results list. Another multicenter study of the American interface for Google found the first incorrect information in $43^{\text {rd }}$ place in the search results. ${ }^{[21]}$ However, in Turkey, negative information was reported in the first 10 search results, similar to search results in England, Australia, France and Italy. ${ }^{[21]}$ Furthermore, a study analyzing 10,380 online data given by websites from 144 countries about vaccination showed that $31 \%$ of data contained incorrect information about vaccination. ${ }^{[24]}$ Finally, it can be said that more websites containing accurate information in the context of vaccination-autism are found in general. In Turkey, more websites with misinformation are found at the top of searches. We believe this may be due to the fact that the headlines of the websites containing the incorrect information are written in a worrying manner.

In this study, though there were statistically significant differences in professional, scientific journals, and health websites about autism and vaccinations, more accurate information was found. Also, incorrect information was found more on other pages and news sites. A website belonging to the government was also found to have accurate information. A study by Arif et al. reported that there was more incorrect information related to vaccinations in Google interfaces on commercial and other pages. ${ }^{[7]}$ Another study reported infor- 
mation supporting anti-vaccination in half of the Twitter samples collected from 2009 to 2015. ${ }^{[25]}$ Finally, it seems necessary to increase the number informative articles about the lack of correlation between vaccination and autism on news websites and government sites. When the scientific journals investigated in our study were examined, one of the top five articles contained references about concerns related to vaccinations in families. However, it was not stated that vaccinations did not cause autism. It is reported that there are no anti-vaccination articles among scientific journals on Google's American interface, whereas English and Australian interfaces have several anti-vaccination scientific articles. In conclusion, it can be said that information related to vaccination is compatible with scientific articles listed on Google searches in Turkey.

When the listings of information in Google results were examined in our study, there appeared to be no difference in the distribution of accurate and incorrect information related to vaccination. Additionally, it was observed that incorrect information was in the bottom half of the search results. Accurate information was listed at the top of the search results, although this situation was not statistically significant. It is known that websites that are visited more often are on the rise in Google's search results, so it can be said that, though not significant, accurate information related to vaccination receives more visits. However, the lack of analysis of visitor numbers in our study is a significant limitation. Additionally, it was observed that articles without named authors were found more often in the first two pages of the search results. According to our findings, although there were no statistically significant differences in terms of the distribution of authors, anti-vaccination information appeared to be written by authors who were not medical doctors. Also, pages written by medical doctors were found listed lower than websites with unnamed authors, though not significant. In conclusion, although pages containing accurate information were at the top of the list in the context of autismvaccination, the Google listing of the pages may be independent of the reliability of the author.

When the reliability marker of JAMA points was examined for pages in our study, although there was no statistically significant difference found in JAMA points between websites containing accurate, incorrect or contradictory information, the JAMA points were higher for pages with accurate information. Additionally, the JAMA points for news sites were statistically significantly lower. Another study evaluating JAMA points reported that the google.com and google.co.uk websites had higher points compared with the localized interfaces in English-Australia, French, and Italian. ${ }^{[21]}$ According to our results, the reliability of anti-vaccination articles on websites and news sites related to this topic in Turkey seems to belower.

Our study makes an important contribution to the literature because it is the first on this topic in Turkey. Additionally, we hope that the study may help to find a solution by ensuring a better understanding of the causes of anti-vaccination movements, which have increased in recent years. The most significant limitation of our study is that the visitor numbers to the websites researched were not evaluated. Although it is known that Google lists websites based on click numbers, the lack of evaluation of visitor numbers is an important limitation resulting in not knowing how often each page was visited. Another limitation of our study is that sites were not researched according to vaccination type. Future studies about this topic are needed to analyze vaccination types and to illuminate whether there is a rejection of any particular type of vaccination.

When families learn that their children have autism, they experience a difficult emotional process. They then enter a period of uncertainty and search the possible causes and treatment of autism in-depth on the internet. Incorrect information includes risks for both families and their children's health. As a result, it is important for families to access accurate information about the causes and treatment of autism such that they can take better care of their children. In conclusion, increasing the numbers of articles and projects by both government and scientific communities to inform the public is important to ensure that families can access accurate information.

Conflict of interest: The author(s) declared no potential conflicts of interest with respect to the research, authorship, and/or publication of this article.

Funding: The author(s) received no financial support for the research, authorship, and/or publication of this article.

\section{References}

1. Prevalence of autism spectrum disorder among children aged 8 years - autism and developmental disabilities monitoring network, 11 sites, United States, 2010. Morbidity and mortality weekly report. Surveill Summ (Washington, D.C: 2002). Mar 28 2014;63(2):1-21.

2. Baio J, Wiggins L, Christensen DL, et al. Prevalence of autism spectrum disorder among children aged 8 years-autism and developmental disabilities monitoring network, 11 sites, United States, 2014. MMWR Surveill Summ. 2018;67(6):1.

3. Haverkate M, D'Ancona F, Giambi C, et al. Mandatory and recommended vaccination in the EU, Iceland and Norway: results of the VENICE 2010 survey on the ways of implementing national vaccination programmes. Euro Surveill. 2012.

4. Taylor LE, Swerdfeger AL, Eslick GD. Vaccines are not associated with autism: an evidence-based meta-analysis of case-control and cohort studies. Vaccine. 2014;32(29):3623-3629.

5. Wakefield AJ, Murch SH, Anthony A, et al. RETRACTED: Ileal-lymphoid-nodular hyperplasia, non-specific colitis, and pervasive developmental disorder in children: Lancet; 1998.

6. Murch SH, Anthony A, Casson DH, et al. Retraction of an interpretation. Lancet. 2004;363(9411):750.

7. Kawashima H, Mori T, Kashiwagi Y, Takekuma K, Hoshika A, Wakefield $A$. Detection and sequencing of measles virus from peripheral mononuclear cells from patients with inflammatory bowel disease and autism. Dig Dis Sci. 2000;45(4):723-729.

8. Bernard S, Enayati A, Redwood L, Roger H, Binstock T. Autism: a novel form of mercury poisoning. Medical Hypotheses. 
2001;56(4):462-471.

9. Offit PA. Vaccines and autism revisited-the Hannah Poling case. N Engl J Med. 2008;358(20):2089-2091.

10. DeStefano F, Bhasin TK, Thompson WW, Yeargin-Allsopp M, Boyle C. Age at first measles-mumps-rubella vaccination in children with autism and school-matched control subjects: a populationbased study in metropolitan Atlanta. Pediatrics. 2004;113(2):259266.

11. Smeeth L, Cook C, Fombonne E. Erratum: MMR vaccination and pervasive developmental disorders: A case-control study (Lancet (2004) 364 (963-969)). Lancet. 2004;364(9448):1856.

12. DeWilde S, Carey IM, Richards N, Hilton SR, Cook DG. Do children who become autistic consult more often after MMR vaccination? Br J Gen Pract. 2001;51(464):226-227.

13. Fombonne E, Zakarian R, Bennett A, Meng L, McLean-Heywood D. Pervasive developmental disorders in Montreal, Quebec, Canada: prevalence and links with immunizations. Pediatrics. 2006;118(1):e139-e150.

14. Price CS, Thompson WW, Goodson B, et al. Prenatal and infant exposure to thimerosal from vaccines and immunoglobulins and risk of autism. Pediatrics. 2010;126(4):656-664.

15. Yoshimasu K, Kiyohara C, Takemura S, Nakai K. A meta-analysis of the evidence on the impact of prenatal and early infancy exposures to mercury on autism and attention deficit/hyperactivity disorder in the childhood. Neurotoxicology. 2014;44:121-131.

16. Bölte S, Girdler S, Marschik PB. The contribution of environmental exposure to the etiology of autism spectrum disorder. Cell Mol Life Sci. 2019;76(7):1275-1297.
17. Fox S, Duggan M. Health online 2013. Health. 2013;2013:1-55.

18. García-Basteiro AL, Álvarez-Pasquín M-J, Mena G, et al. A publicprofessional web-bridge for vaccines and vaccination: User concerns about vaccine safety. Vaccine. 2012;30(25):3798-3805.

19. Betsch C, Brewer NT, Brocard P, et al. Opportunities and challenges of Web 2.0 for vaccination decisions. Vaccine. 2012;30(25):37273733.

20. Jang SM, Mckeever BW, Mckeever R, Kim JK. From social media to mainstream news: The information flow of the vaccine-autism controversy in the US, Canada, and the UK. Health Commun. 2019;34(1):110-117.

21. Arif $\mathrm{N}, \mathrm{Al}$-Jefri $\mathrm{M}$, Bizzi IH, et al. Fake news or weak science? Visibility and characterization of anti-vaccine webpages returned by Google in different languages and countries. Front Immunol. 2018;9:1215.

22. Maki A, Evans R, Ghezzi P. Bad news: analysis of the quality of information on influenza prevention returned by Google in English and Italian. Front Immunol. 2015;6:616.

23. Ruiz JB, Bell RA. Understanding vaccination resistance: vaccine search term selection bias and the valence of retrieved information. Vaccine. 2014;32(44):5776-5780.

24. Larson HJ, Smith DM, Paterson P, et al. Measuring vaccine confidence: analysis of data obtained by a media surveillance system used to analyse public concerns about vaccines. Lancet Infect Dis. 2013;13(7):606-613.

25. Tomeny TS, Vargo CJ, El-Toukhy S. Geographic and demographic correlates of autism-related anti-vaccine beliefs on Twitter, 200915. Soc Sci Med. 2017;191:168-175. 